\title{
LANGUAGE, EDUCATION AND THE NEW SOUTH AFRICA
}

\author{
MARY GILMARTIN \\ Department of Geography, University College Dublin, Belfield, Dublin 4, Ireland. \\ E-mail: mary.gilmartin@ucd.ie
}

Received: August 2003; revised March 2004

\begin{abstract}
Issues of language and education are central to the process of nation building in the new South Africa. In this paper, I examine the rhetoric and the practice of the intersections of South Africa's language and education policies. While early education policy documents are predicated on the need to reassert the importance of African languages in relation to English and Afrikaans, the official languages during apartheid, these discourses of language equality are now being replaced with discourses of utility. I examine this change at the level of national policy, and also in practice in the province of Mpumalanga, where English is increasingly coming to dominate the spaces of education, and Afrikaans and African languages are becoming more marginalised. I argue that this policy shift and related practices fundamentally undermine broader claims to racial and ethnic equality in the new South Africa.
\end{abstract}

Key words: Language, education, South Africa

\section{INTRODUCTION}

The building blocks of this nation are all our languages working together, our unique idiomatic expressions that reveal the inner meanings of our experiences. These are the foundations on which our common dream of nationhood should be built (Mbeki 1999)

For South African President Thabo Mbeki, speaking in August 1999, the relationship between language and national identity is clear. The new nation would be based on the erasure of borders between languages and language users who were historically separated under the practices of apartheid. English and Afrikaans, privileged and protected languages in the apartheid era, would no longer be prioritised over the array of languages spoken by black South Africans. Instead, South Africa's diversity of languages would provide a rainbow foundation for the rainbow nation.
It is telling that Mbeki described languages as the building blocks of the new nation. Language has been marked as crucial both in the establishment and maintenance of colonial rule, and in the establishment and maintenance of new postcolonial identities: it is, as James Scott comments, 'a general tool that can be bent to countless ends by virtue of its adaptability and flexibility' (Scott 1998, pp. 143-144). Colonial writers have pointed to language as a civilising tool; postcolonial writers have identified the paradox of language both as a tool of control and also as a tool of liberation (see, for example, Achebe 1975; Alexander 1999; Derrida 1998; Fanon 1963, 1986; Ngũgĩ wa Thiong'o 1986; Retamar 1989). Systems of education have been crucial in establishing the status of languages across a range of colonial and postcolonial settings. In colonial periods, the spaces of education were used to promulgate a particular image of civilisation, and did so in and through the language of the colonial power. As John Willinsky 
observes in relation to English, though his comments are relevant to a range of colonial languages, 'it was made an instrument of domination and silencing; it was used to regulate and police access to authority and knowledge among colonized peoples' (Willinsky 1998, p. 191). Yet language may also be used as a tool of nation-building, as Benedict Anderson (1983) has highlighted. In postcolonial periods, the spaces of education are used to invent or reinvent the new nation, and language is often the means in and through which the disjuncture with the past is most forcibly expressed. In Ireland, for example, the Irish language was given legal priority over English after independence from Britain, and Irish was instituted as a compulsory subject through primary and secondary schooling. Afrikaans was used as a tool of Afrikaner nation-building in postcolonial South Africa (Coetzee et al. 2001, p. 2). Postcolonial India tried to establish Hindi as the country's official language for administrative and educational purposes (Willinsky 1998, p. 204). More recently, East Timor has instituted Tetum and Portuguese as the country's official languages, in reaction to the imposition of Bahasa Indonesian as the language of instruction in East Timorese schools during Indonesian occupation. Though many of the earlier initiatives have foundered in the face of the increasing dominance of English as a global language, they remain important for understanding the ways and means by which the stories of new nations are recounted: in schools, and in languages associated with the struggle against colonialism. ${ }^{1}$

In post-apartheid South Africa, the project of nation building aims towards a new and inclusive definition of the nation that both addresses and overturns the legacies of apartheid. Questions of language and education are crucial to this process. New language policies have, as their goal, the reversal of the language hierarchy that existed under apartheid. New education policies are designed to dismantle the racially segregated system of education that developed under apartheid, and to ensure that children of all races have access to a similarly high standard of education. Both of these sets of policies are informed by the Constitutional commitment to human dignity, equality, rights and freedoms, as well as non-racialism and non-sexism (Republic of South Africa 1996). These commitments to equality materialise in the schools of South Africa. Education is clearly marked as a space where the issues of language inequality and educational inequality can be addressed in conjunction, and in the overall context of creating a new and inclusive South Africa.

In this paper, I examine the rhetoric and the practice of the intersections of language and education policy in the new South Africa. The paper has two significant sections. The first provides an account of language in education policy change at the national level in South Africa. Through a detailed reading of official documentation, I chart how early aspirations towards language equity, codified in the Constitution, become diluted in successive legislation when faced with practical difficulties of implementation. The second section, which is based on fieldwork that I carried out in South Africa in the period from 1998 to 2000 , looks at the implementation of policy in Mpumalanga, one of the country's nine provinces. In this section, I draw on field observations and interviews with a range of educators and civil servants to show how, despite official aspirations towards language equity, African languages remain marginalised in schools and English is becoming increasingly influential - trends that are also highlighted in research carried out in other provinces. I conclude with reflections on the impacts of these practices on the project of nation building, and argue that the aspiration to racial and ethnic equality is fundamentally undermined by the rhetoric of utility that is coming to dominate language in education policy in the new South Africa.

\section{LANGUAGE AND EDUCATION POLICY IN THE NEW SOUTH AFRICA}

The apartheid-era South African education system was highly segregated. Children were separated on the basis of race and/or language, and teaching for all students generally took place through the medium of either English or Afrikaans. As a consequence, the medium of instruction for the majority of white students was their mother tongue, while the majority of black students were taught through English, which was often their second or third language. English and Afrikaans were compulsory subjects for matriculation for all students, and African 
Table 1. Dominant home language by number, percentage, and province(s) where this is the majority home language, South Africa, 2001.

\begin{tabular}{lccl}
\hline Language & Number of speakers & Percentage & Provinces \\
\hline English & $3,673,203$ & 8.20 & \\
Afrikaans & $5,983,426$ & 13.35 & Northern Cape, Western Cape \\
Sesotho sa Leboa & $4,208,980$ & 9.39 & Limpopo \\
IsiZulu & $10,677,305$ & 23.82 & KwaZulu-Natal \\
SiSwati & $1,194,430$ & 2.66 & \\
IsiNdebele & 711,821 & 1.59 & North West \\
Setswana & $3,677,016$ & 8.20 & Free State \\
Sesotho & $3,555,186$ & 7.93 & Eastern Cape \\
Xitsonga & $1,992,207$ & 4.44 & \\
IsiXhosa & $7,907,173$ & 17.64 & \\
Tshivenda & $1,021,757$ & 2.28 & \\
Other & 217,293 & 0.48 & \\
\hline
\end{tabular}

Source: Statistics SA. Available at <http://www.statssa.gov.za>, accessed March 2004.

languages had a subordinate position in the apartheid education system. The situation in schools mirrored the situation in the broader society. In apartheid South Africa, there were two official languages: English and Afrikaans. According to official government statistics, English was the home language of just over 9 per cent of the population, while Afrikaans was the home language of just over 15 per cent of the population. The vast majority of South Africans (around $75 \%$ ) had, as their home language, one of nine 'African' languages. It was estimated that roughly half the population of South Africa spoke neither English nor Afrikaans, and that about two thirds of African language speakers could not speak English (DESA 1994). The designation of English and Afrikaans as official languages helped to reinforce apartheid inequalities, because it consigned the majority of South Africans to official communications in languages in which they were not completely conversant.

As apartheid ended, the issue of language equity came to the forefront. The publication of the South African constitution, in interim form in 1993 and in final form in 1996, was an important marker. The Constitution declared 11 official South African languages: as well as English and Afrikaans, the other official languages are isiZulu, isiXhosa, siSwati, Tshivenda, Sepedi, Sesotho, Setswana, Xitsonga and isiNdebele. ${ }^{2}$ The relative importance of each of these languages is shown in Table 1. Under the provisions of the Constitution, all languages were to be given equality of treatment, and the ultimate aim was the creation of a society where African languages were as valued and as important as European languages. In particular, the Constitution asserted that, given the diminished status of indigenous languages, "the state must take practical and positive measures to elevate the status and advance the use of these languages' (Republic of South Africa 1996, Section 6(1)).

During the apartheid era, conflicts had arisen over the issue of language in education. In particular, the Soweto uprising in 1976 was a reaction against the proposed introduction of Afrikaans as the medium of instruction in black schools. While this proposal was never realised, the ensuing conflicts marked language in education policy and practice as a space of both oppression and liberation. In post-apartheid South Africa, the libratory potential of language in education was emphasised. The Constitution provided specific guidelines in relation to the role of language in education. Section 29(2) provided for the right to instruction in the language of the applicant's choice 'where that education is reasonably practicable', while Section 29(3) provided the right to establish educational establishments based on a common culture, religion or language (Republic of South Africa 1996). Constitutional provisions in relation 
to language were quickly incorporated into education policy documents. The ANC published its Implementation Plan for Education and Training in 1994. In this plan, which would underpin the later White Papers in education, particular attention was paid to language. Language policy for the period to 1999 was organised around two central ANC goals: 'affirmative action to encourage the educational use of African languages at all levels of education; and concretizing the effective right to choose which language or languages are used as the language(s) of learning and which languages are studied as subjects' (ANC 1994, p. 124). The plan suggested a variety of types of affirmative action to be directed towards the successful implementation of a new language in education policy. These included extra credit points for all African languages at all certification stages; the development of improved teaching resources for African languages; and an insistence that proficiency in African languages should be a key criterion when appointing both academic and administrative staff. In addition, the plan insisted that language criteria should not be used to limit entry to schools, and that the requirement to take both English and Afrikaans as school subjects be lifted (ANC 1994, pp. 129-131).

The ANC Implementation Plan was the most forceful assertion of the need for and nature of change in relation to language in education. It was followed by a number of legislative and policy documents that, while making overtures to the intent of the plan, successively diluted the scope for change. The first Education White Paper (gazetted in March 1995), for example, insisted that learners and/or their parents or guardians must be allowed to choose the language of instruction but subject to limitations. In particular, the White Paper commented that a school has no obligation to offer a particular language chosen by a learner if it is not 'reasonably practical' to do so (DESA 1995, p. 43). The 1997 Language in Education Policy document removed the requirement to study English and Afrikaans (instead, learners have to study 2 languages, at least one of which is official). It also asserted the importance of 'the individual's language rights', but placed those rights firmly within 'the overall framework of the obligation on the education system to promote multilingualism' (DESA 1997, p. 5). In other words, the responsibility for the promotion of multilingualism ultimately rests with the governing bodies of individual schools, and schools are told that if there are less than 40 students in Grades 1-6, or less than 35 students in Grades 7-12 requesting instruction in a specific language, there is no mandate on an individual school to provide it. This represents a further dilution of policy, and an implicit acceptance that the majority of students will continue to be taught in English or Afrikaans despite the constitutional commitment to other official languages.

Only two years after the publication of Language in Education Policy came further evidence of the marginalisation of the language issue. When Professor Sibusiso Bengu published his status report in June 1999, after five years as education minister, the issue of language was not addressed at all. The status report is written in English, and African languages - either in practice or in theory - are not visible (DESA 1999a). This invisibility is repeated in Tirisano, the political mandate for the Department of Education for the five-year period from January 2000 to December 2004. Prepared under the direction of Professor Kader Asmal, the second education minister, Tirisano outlines the Department's five core programme areas (DESA 1999b, 2000a, 2000b). These are HIV/AIDS; school effectiveness and teacher professionalism; literacy; further and higher education and training; and organisational effectiveness. Each programme area is divided into specific projects, but none of these projects, or none of the core areas, address the issue of language.

Rather than dealing with the issue of language in formal departmental documentation, Minister Asmal formed a working group on values in education in February 2000. Their report, published in July 2000, contains a section on multilingualism - the first such emphasis since the 1994 ANC Implementation plan (DESA 2000c). The authors of the report argued for the promotion of two main values in relation to language in education. The first is the principle of mother-tongue education - studying through one's first language. The second is the need to foster multilingualism. The working group made specific reference to the lack of exposure of white South Africans to African languages. In the past, they observed, the onus had been on African language speakers to learn 
Table 2. Dominant home language, Mpumalanga, 2001.

\begin{tabular}{|c|c|c|c|}
\hline Language & Number of speakers & Percentage & National percentage \\
\hline English & 51,833 & 1.66 & 8.20 \\
\hline Afrikaans & 192,129 & 6.15 & 13.35 \\
\hline Sesotho sa Leboa & 336,451 & 10.77 & 9.39 \\
\hline IsiZulu & 822,934 & 26.35 & 23.82 \\
\hline SiSwati & 963,188 & 30.84 & 2.66 \\
\hline IsiNdebele & 377,688 & 12.09 & 1.59 \\
\hline Setswana & 84,911 & 2.72 & 8.20 \\
\hline Sesotho & 114,169 & 3.66 & 7.93 \\
\hline Xitsonga & 117,921 & 3.78 & 4.44 \\
\hline IsiXhosa & 46,553 & 1.49 & 17.64 \\
\hline Tshivenda & 5,935 & 0.19 & 2.28 \\
\hline Other & 9,277 & 0.30 & 0.48 \\
\hline
\end{tabular}

Source: Statistics SA. Available at <http://www.statssa.gov.za>, accessed March 2004.

English and Afrikaans. English and Afrikaans speakers were not expected to become proficient in African languages. They recommended that all learners acquire at least one African language - to be determined at the provincial level - during their time at school. In order to support these recommendations, it would be necessary to reorganise teacher training, to introduce inservice courses in African languages, to develop teaching and reading materials, and to enhance the resources available to develop African languages. These initiatives would need to be supported by changes in the broader society. In particular, appointments to the public sector should require at least trilingualism, and multilingual proficiency should be rewarded on an individual and company basis. These changes, the working group argued, 'would add considerably to reconciliation processes and the promotion of a common South African citizenship' (DESA 2000c). As yet, few concrete initiatives have been taken to put their recommendations into practice, particularly in relation to the teaching, learning and use of African languages. In fact, the recent Values in Education Programme of Action, published in June 2002, refers to language once: in the context of 'cultural heritage' (DESA 2002). There are no definite plans in this programme in relation to language in education. The removal of the issue of language from policy to working group report represents the practical difficulties of administering an education system with 11 official languages. It also represents the replacement of discourses of equity with discourses of utility, a trend that is obvious at provincial and local as well as at national levels.

\section{POLICY INTO PRACTICE}

How is language policy being put into practice in the schools of South Africa? This paper chose to examine this question in Mpumalanga, one of the nine provinces in South Africa (see Figure 1). Mpumalanga, the northeastern province bordering both Mozambique and Swaziland, is one of the more linguistically diverse provinces in South Africa - it is one of only two provinces in South Africa where there is no majority dominant home language (see Table 1). It contains the old homelands of Kangwane and KwaNdebele, has an extensive border with KwaZulu-Natal, and also borders the old homelands of Lebowa and Gazankulu. As a consequence, siSwati, isiNdebele, isiZulu, and Sesotho sa Leboa are all widely spoken, together with Afrikaans and English. The dominant languages in Mpumalanga, according to the 2001 Census, are shown in Table 2. Mpumalanga is also useful to study because it faces budgetary difficulties in relation to education. In 1997-98, per capita expenditure on education was only 89 per cent of the national average. Pupil/teacher ratios in the province were extremely high: 38:1 for primary schools, and 33:1 for secondary schools. There were also 


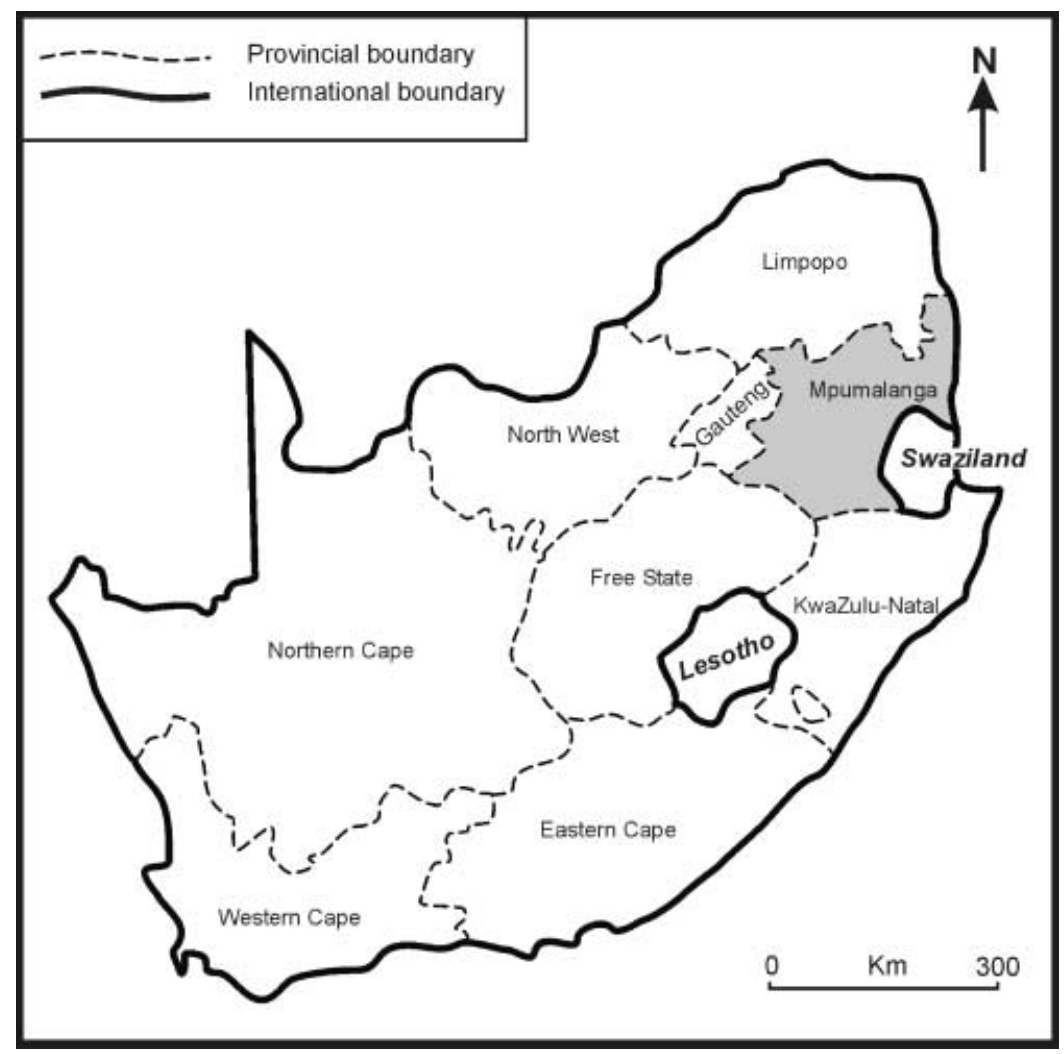

Figure 1. Political map of South Africa's new provinces.

problems in relation to teacher morale. Over 1,000 teachers had applied for voluntary redundancy by April 1997, but only 8 of those applications had been approved (South African Institute of Race Relations 1998, pp. 136-165).

I carried out fieldwork in South Africa from November 1998 to February 1999, from November 1999 to March 2000, and in February 2001, when I worked as the research assistant on an NSF-funded project (Rangan \& Gilmartin 2002). ${ }^{3}$ In the course of this project, I spent a considerable period in Mpumalanga, which was experiencing a crisis in education because of its low pass rate in the Matriculation examination in 1997 and the subsequent fraud in reporting the 1998 examination results. Through Mpumalangabased contacts at the Danish-funded 'Learning for Sustainability' project, I was able to gain access to circuit, district and provincial level administrators. In addition to personal and group interviews with these officials, I also attended training courses and meetings. In conjunction with project staff, I visited a number of black rural schools, where I observed training sessions, and conducted group interviews. The people I met through the project directed me to other teachers, union officials and administrators in Mpumalanga province, who I interviewed in depth about their experiences of educational change in the new South Africa. In tandem with these introductions, I also made direct contact with teachers and principals in white and private schools in Mpumalanga, with journalists based in the province's main news agency, and with national level officials at the Department of Education, who I also interviewed. The interviews were unstructured, but had a primary focus on experiences of change with respect to language and to school integration.

Mpumalanga is divided into ten education districts (see Figure 2), which together have responsibility for 545 combined and secondary 


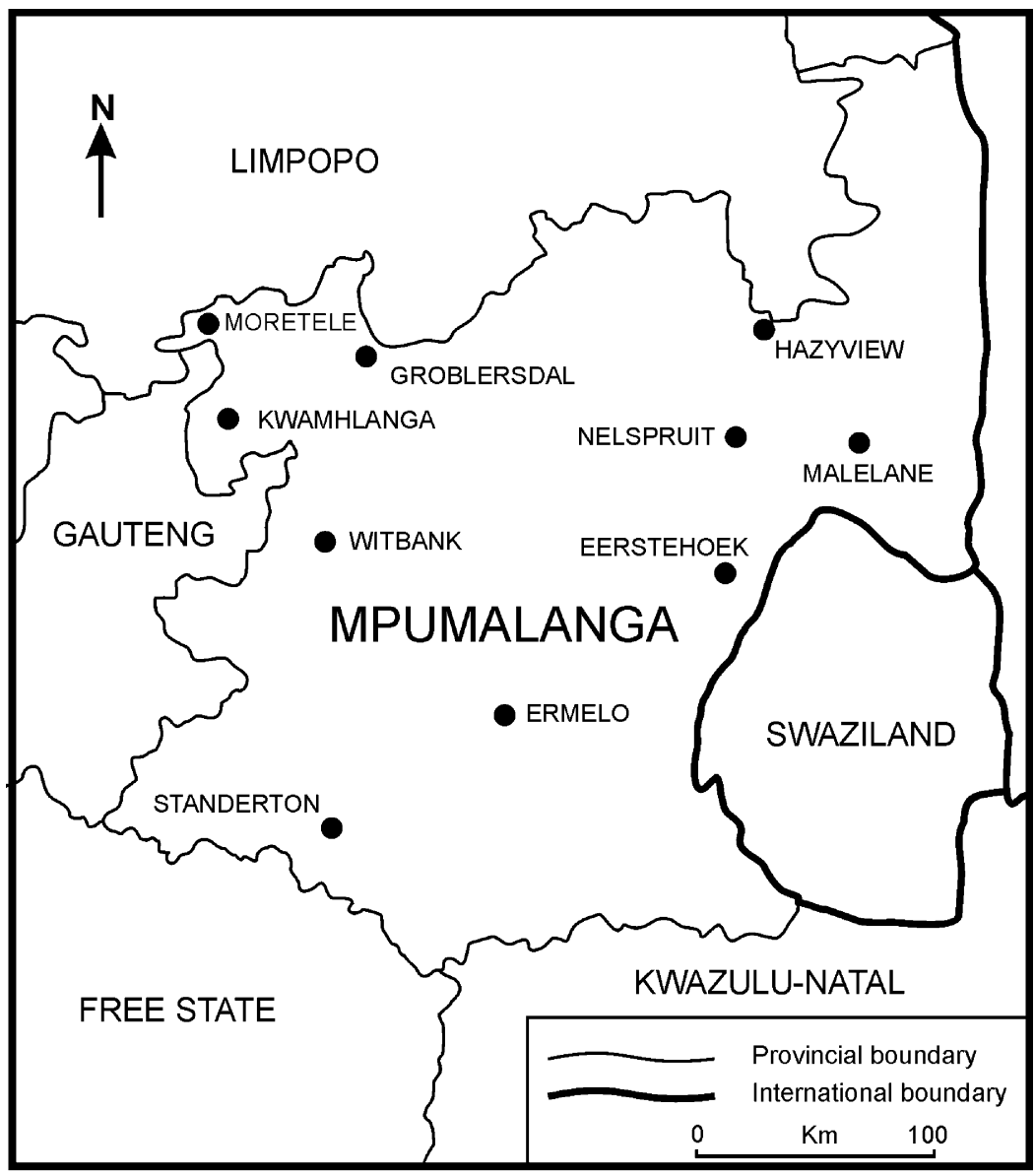

Figure 2. Education district offices in Mpumalanga province.

public schools. The Provincial Department of Education lists 14 different languages that are taught in these schools: ten of the country's official languages, together with German, French, Portuguese and Latin. Of these, English and Afrikaans are the most popular. English is taught in almost 99 per cent of the schools in Mpumalanga, while Afrikaans is taught in over 92 per cent of schools. In contrast, the most popular African languages (isiZulu, Sesotho sa Leboa, and siSwati) are each taught in less than one third of schools. Table 3 shows the number and percentage of schools offering each of the 14 languages in Mpumalanga province. While English and Afrikaans are taught in all ten education districts, African languages tend to be specific to particular districts. For example, 70 per cent of schools offering isizulu are located in just four districts, 77 per cent of schools offering Sesotho sa Leboa are located in just three districts, and all but one of the schools offering siSwati can be found in four districts. This pattern is historically explicable in relation to the location of homelands. However, the old borders of apartheid do not explain the persistence of apartheid-based distinctions, such as the continuing prominence and importance of English and Afrikaans.

Public discourse around the issue of language in education in Mpumalanga province focuses, almost exclusively, on one key issue: will Afrikaans schools become dual medium? ${ }^{4}$ A newspaper report in 1998 outlined the basic problem. The region 'is currently under-equipped to deal with 
Table 3. Languages taught at combined and secondary public schools in Mpumalanga province, South Africa.

\begin{tabular}{|c|c|c|c|}
\hline Language & Status & Number of schools & Percentage \\
\hline English & Official & 539 & 98.9 \\
\hline Afrikaans & Official & 501 & 91.9 \\
\hline Sesotho sa Leboa & Official & 174 & 31.9 \\
\hline IsiZulu & Official & 170 & 31.2 \\
\hline SiSwati & Official & 134 & 24.6 \\
\hline IsiNdebele & Official & 111 & 20.4 \\
\hline Setswana & Official & 31 & 5.7 \\
\hline Sesotho & Official & 15 & 2.8 \\
\hline Xitsonga & Official & 6 & 1.1 \\
\hline German & & 3 & 0.6 \\
\hline French & & 3 & 0.6 \\
\hline IsiXhosa & Official & 2 & 0.4 \\
\hline Portuguese & & 2 & 0.4 \\
\hline Latin & & 1 & 0.2 \\
\hline
\end{tabular}

Source: Department of Education, Mpumalanga (Personal communication).

a boom in the number of English speaking pupils', wrote Dumisane Lubisi, 'while its Afrikaans speaking population seems to be shrinking' (Lubisi 1998c). This boom is connected to the process of school integration in Mpumalanga. Integration has, in practice, one meaning: the movement of black students to formerly white schools. There is no movement of white students to black schools, and there are very limited attempts to change the racial balance of either teaching staff or governing bodies of formerly white schools. The black students who move to white schools want to move to Englishmedium schools for a variety of reasons. These include the historical association of Afrikaans with apartheid, the belief that English is the language of social advancement, and the practical reason that English is often the medium of instruction in black township schools.

Despite the Constitutional commitment to equality of treatment for all official languages, two significant trends are emerging within the spaces of education in Mpumalanga, and within South Africa more generally. The first is the marginalisation of African languages and African language speakers. The second is the increasing Anglicisation of education in South Africa.

The marginalisation of African language speakers - The marginalisation of African languages and African language speakers happens in two significant ways. One such way is structural. The national and provincial systems of examination and progression militate against African languages. Between Grades 10 and 12, all students have to pass one language at first language level and one language at second language level to progress to the next stage. English and Afrikaans are examined at first, second and third language levels, while African languages are examined at first and third language levels only. As a consequence of this structural inequity in examination practice, English and Afrikaans continue to receive most attention in terms of effort and resources, since both can be taken at first and second language level. This is particularly the case in formerly white schools, which continue to teach English and Afrikaans, and make little or no concession to their growing population of black students who speak neither as a first language. However, black schools are also constrained by this imbalance. In Mpumalanga, most devote their language teaching efforts to just three languages: English, Afrikaans and one African language. It is very rare for black schools to teach more than one African language. For example, each of the ten education districts in Mpumalanga has a predominant African language that is taught in at least half, and in some cases over 90 per cent of schools. Only two of these districts, however, 
have a second African language that is taught in over half its schools, and just three districts obviously have schools that offer more than one African language as a subject. Even when schools offer African languages, effective teaching is hampered by a significant lack of teaching resources. For example, Sepedi (Sesotho sa Leboa) textbooks provided by the provincial education department in 1997 were poorly written, containing Setswana and Zulu though claiming to be Sepedi (Lubisi 1997).

Language is also used to discriminate against black students. One administrator I interviewed claimed that 'in English-medium schools, black students are likely to be flunked in their first year'. A black teacher told me that 'there is subtle discrimination in many white schools' that is often based on command of language. He felt that English-medium schools were the worst offenders in this regard. Certainly, when I visited English-medium schools, I was struck by the ways in which black students were subtly deprecated. For example, in a formerly white school, I was told that the education of black students at township schools was inadequate and they needed special help. Because many black students are 'language disadvantaged', they take one less academic subject in the school, and instead have 'language enrichment' classes with gap year students from Britain. The language enrichment classes are not formal - they are conducted by whoever appears as volunteer staff at the school each year. By reducing the number of academic subjects available to black students, the school is promulgating a message of black intellectual inferiority, a trend also noted in a national newspaper article on an Afrikaans-medium school in Mpumalanga, Hoër en Laer Skool Balfour. Journalist Julia Grey wrote of how black students attending the school were explicit about their experiences in relation to being made feel inferior. One student told her that the school left him "with the impression that if a black boy goes there, he is going to fail. I got the impression that a black man is stupid' (Grey 2001b).

These experiences are not unique to Mpumalanga, or to the contemporary period. Steve Biko observed, in an interview with Donald Woods, that because black students often study through and read books in English - their second language - they 'never quite catch every- thing that is in a book... You understand the paragraph but you are not quite adept at reproducing an argument that was in a particular book, precisely because of your failure to understand certain words in the book. This makes you less articulate as a black man generally' (Woods 1978, pp. 128-129). Biko made these comments in the $1970 \mathrm{~s}$, but they continue to be relevant in the new South Africa. Neville Alexander, director of the Project for the Study of Alternative Education, has been outspoken about this issue. Alexander described the current situation in South Africa as a default policy based on shortterm economic calculations, but with potentially disastrous consequences (Alexander 2001b). It is impossible, he argued, for South African people to be spontaneous, creative and selfconfident 'if they are forced to communicate always in a second, for most of them actually a foreign language but in any case one of which they do not have an adequate command' (Alexander 2001a). A range of research supports Alexander's assertion. For example, research in Western Cape found that language was the central reason in student matriculation failure. Students who wrote the examination in their mother tongue performed best, while those who could not do so performed worst (Alexander 2001b). The Department of Education gave such students extra marks in the matriculation exams of 1998 to acknowledge their difficulties, a move criticised as inadequate and avoiding the real problem (Desai 2001, p. 337). Research carried out by Coetzee et al. (2001) found that academic progress is hampered when learners have limited skill in the medium of instruction. They also highlighted research carried out by the University of the Free State, which found that native Sesotho speakers fared best in history classes taught through Sesotho, and worst in classes conducted through English. Classes in English, observers found, were rigid and artificial and had virtually no learner participation. In classes taught through Sesotho, there was 'spontaneous interaction between teachers and pupils' (Coetzee et al. 2001, p. 10). Research in Khayelitsha, an African township outside Cape Town, in a primary school that had introduced English-medium instruction for its Xhosa-speaking students, found that learners were struggling to express themselves in English, while their self-expression in Xhosa 
was significantly more complex and developed (Desai 2001).

The Anglicisation of education - Throughout 1998 and 1999, Afrikaans schools in Mpumalanga battled with the provincial department, which was trying to ensure they became dual medium to cope with the increased demand for English-medium teaching. Many initially refused, then insisted on additional resources to cope with increased expenses (Lubisi 1998a, 1998b). Now, Afrikaans schools throughout Mpumalanga are gradually beginning to introduce English-medium classes, but the result is racial segregation. A newspaper report on one Mpumalanga school, Hoër en Laer Skool Balfour, described how the mainly white Afrikaans students and the mainly black English students learn in separate classes. The words of the principal were telling. He said that 'we look at it as two separate schools on one campus' (Grey 2001a).

Educators, politicians and administrators are critical of the stance taken by Afrikaans schools in Mpumalanga. Both the education MEC (Member of the Executive Council, the provincial cabinet) and the education spokesperson strongly attacked Afrikaans schools in late 1999. The MEC, Craig Padayachee, claimed that the school governing bodies (SGBs) of Afrikaans schools were often non-inclusive, reactionary and racist. His remarks were echoed by the spokesperson, Peter Maminza, who declared that Afrikaans schools were 'hiding behind issues of language and culture in a racist attempt to derail transformation or the integration of education' (Arenstein 1999a). The principal of a formerly white English-medium school in Mpumalanga complained to me that Afrikaans schools had resisted the introduction of Englishmedium classes, claiming there was not enough interest. 'I know that's not true,' he told me, because he and his colleague in English-medium schools had referred many people to them. 'Afrikaans schools have capacity', he said. 'We don't. We are already overcrowded. But Afrikaansspeaking headmasters are very powerful and influential in this area.'

Public disapproval of the role and reactions of Afrikaans schools in Mpumalanga, particularly when couched in accusations of racism, detract from the sense of dislocation felt by many Afrikaners. Freedom Front provincial leader, Hein Mentz, argued that dual medium instruction was an attempt to undermine the independence of Afrikaners, and 'a death knell for Afrikaans as a mother tongue' (Arenstein 1999b). Other responses are more muted, and often described in practical terms. 'If we must take a Grade 8 English class, we will', an Afrikaner principal told me, 'but where does a school like ours get English-medium teachers? These are the practical issues'. But this emphasis on the practical masks the broader ideological concerns that underpin resistance to dualmedium schools. In particular, the Afrikaner community is concerned with protecting the status of the Afrikaans language and Afrikaner culture. As one Afrikaner teacher I interviewed commented, 'schools must have a certain culture, and Afrikaans schools want to remain Afrikaans'.

In the new South Africa, many Afrikaners feel that their language is under threat and believe that, just as English is perceived as the language of social mobility, Afrikaans is the language of apartheid and as such deserves no protection. 'It has been stated openly', Antjie Krog wrote, 'that Afrikaans is the price that Afrikaners will have to pay for Apartheid. Was it not a debate for many years on Robben Island: What do we do with the language of the boere?' (Krog 1999, p. 149). Many Afrikaners believe that multilingualism is 'a smokescreen behind which Anglicisation is taking place' (Coetzee et al. 2001, p. 1). Certainly, English is becoming the dominant language of communication in South Africa. Coetzee et al. (2001) were highly critical of government practice in this regard. 'Because the leaders speak mainly in English during public appearances', they wrote, 'the perception arises that people who have achieved something in life speak English' (Coetzee et al. 2001, p. 7). As a consequence, many parents and learners want teaching to take place through English. Students in schools in South Africa 'want to learn English', Gary Barkhuizen recently observed, 'and their parents agree with them' (Barkhuizen 2002, p. 499). Barkhuizen interviewed high school students in Eastern Cape and Western Cape who studied Xhosa as a first language and English as a second language. He noted that students viewed English as significantly more useful than Xhosa, particularly in relation to 
employment prospects. Over half of the students believed that English should be the language of learning and teaching, in contrast to the 16 per cent who believed that it should be Xhosa (Barkhuizen 2002, pp. 505-509). In the words of a recent submission to the Department of Education, South African languages other than English are now 'subject to steady and irreversible erosion' as a result of benign neglect (Gerwel 2002).

\section{CONCLUSION}

It is when the borderline between one language and another is erased, when the social barriers between the speaker of one language and another are broken, that a bridge is built, connecting what were previously two separate sites into one big space for human interaction, and, out of this, a new world emerges and a new nation is born (Mbeki 1999).

Language policy in South Africa is highly aspirational, as evidenced by this further extract from President Mbeki's 1999 speech to the Afrikaanse Taal en Kultuurvereniging (ATKV). Education is crucial to the successful implementation of language policy, and the successful rehabilitation of African languages within the new South Africa. But the example of Mpumalanga, together with the research initiatives from other provinces in South Africa, shows the practical difficulties in administering an education system with eleven different official languages. These difficulties are exacerbated by the lasting economic, political and cultural effects of apartheid, which have created a nationally uneven tapestry in relation to education. The new nation is undergoing a tricky birth.

Certainly, English is becoming the lingua franca in the new South Africa. As the language of government, business and the media, it has connotations of social advancement and progress. The relationship between the English language and forces of globalisation have also been noted: English is the language of international air traffic communication, technology and entertainment activities, and it is estimated that almost 600 million people worldwide speak English as a first or second language (Short et al. 2001, p. 3). As Desai commented, the trend towards official monolingualism in practice is justified in terms of globalisation: South Africa, the argument goes, 'can compete internationally only through the medium of English' (Desai 2001, p. 331). Achebe described this as 'the fatalistic logic of the unassailable position of English' (quoted in Desai 2001, p. 331). This trend towards monolingualism, and towards the primacy of English, is - for some - a positive occurrence independent of, and in fact in opposition to, globalisation. Bill Ashcroft, for example, describes the potential of the English language as a tool of discursive resistance (Ashcroft 2001, p. 326).

Yet the unassailable logic of English means that, despite the Constitutional safeguards, the status of all languages other than English is under increasing threat. Jacques Derrida described a similar process in his account of his school years in Algeria (Derrida 1998). He wrote of the disappearance of Arabic as both an official and an everyday language, and its increasing displacement to the space of the school as an alien language. It was possible to study Arabic - though not Berber - as an optional subject in school, thus giving Arabic the same status as English, German and Spanish. Though it was possible, virtually no lycée students chose to study the language. 'We knew it was allowed', Derrida wrote, 'which meant anything but encouraged' (Derrida 1998, pp. 37-38). Derrida describes this as the interdict - the subtle, often hidden ways in which previously centred languages are increasingly restricted and replaced. In many ways, the interdict represents unwritten laws - the laws of acceptance, of community and of belonging, but also the laws of rejection and exclusion - to which people submit passively (Derrida 1998, p. 38).

In the new South Africa, an interdict is forcing the gradual removal of all languages but English from the construction of discursive communities within the sphere of education. Policy documents are written in English, using a nominally inclusive language of belonging that ultimately serves to obstruct challenges to educational practice. Educational practice, in conjunction with broader societal practices, continues to discriminate in favour of English and against African languages and, increasingly, Afrikaans. The impact for the majority, who speak neither English nor Afrikaans as a first language, is a continued sense of inferiority, 
and an exclusion from full participation in the nation-building project. South African education policy and practice, which now focuses on the utility of English while using the rhetoric of equity for all languages, serves to fundamentally undermine the hope of racial and ethnic equality in the new South Africa.

\section{Notes}

1. Issues of language, education, national identity and postcolonialism are rarely considered together within geography. Recent debates around language have focused on the Anglicisation of the discipline (see, for example, Desbiens 2002; Desforges \& Jones 2001; Garcia-Ramon 2003; Short et al. 2001). Debates on education often focus on the nature of geographical education, occasionally within the context of colonialism or in terms of the construction of national identity (see, for example, Paasi 1999; Ploszajska 1999; Schnell 1999). While there is a growing literature on the role of postcolonialism in geography, it is often criticised for not engaging with the material consequences of colonialism (see Nash (2002) for a useful summary). Clive Barnett has written about language policy in South Africa, but in the context of media reform (Barnett 1999, 2000). This paper draws together these apparently disparate strands in the study of the direct relationship between language, spaces of education, and the spaces of the nation.

2. Sepedi is also known as Sesotho sa Leboa or as North Sotho. Sesotho is also known as South Sotho.

3. The project, entitled 'Common Access Lands and Sustainable Rural Development in South Africa', was directed by Dr. Haripriya Rangan of Monash University, Melbourne.

4. Dual medium means that instruction will be provided in two languages - in this case, Afrikaans and English - in the same classroom. In practice, it tends to work as a parallel medium: separate classes for each language of instruction.

\section{REFERENCES}

Achebe, C. (1975), The African Writer and the English Language. Reprinted in P. Willians \& L. Chrisman, eds., Colonial Discourse and PostColonial Theory, pp. 428-434. New York: Columbia University Press.
African National Congress (ANC) (1994), Implementation Plan for Education $\mathcal{E}$ Training. Johannesburg: ANC Education Department.

Alexander, N. (1999), English Unassailable but Unattainable: The Dilemma of Language Policy in South African Education. Available at <http:// www.und.ac.za/und/ling/archive/alex-01.html>, accessed May 2002.

Alexander, N. (2001a), We are fiddling while the country's schools are burning. Mail E् Guardian, 2-8 February, pp. 28-29.

Alexander, N. (2001b), Rehabilitating mothertongue education and creating a system of bilingual education as a transitional strategy. Paper presented at the Values, Education and Democracy Conference. Kirstenbosch, 22-24 February. Available at $<$ http:// education.pwv.gov.za/Conferences/Values/Neville_ Alexander.htm>, accessed April 2001.

Anderson, B. (1983), Imagined Communities: Reflections on the Origins and Spread of Nationalism. London: Verso.

Arenstein, J. (1999a), Afrikaans Governing Bodies Interfere in School Management - Padayachee. African Eye News Service, 17 October.

Arenstein, J. (1999b), Mpumalanga Slammed for Criticising Afrikaans Schools. African Eye News Service, 19 October.

Ashcroft, B. (2001), Language and Race. Social Identities 7, pp. 311-328.

BARKHUIZEN, G.P. (2002), Language-in-education Policy: Students' Perceptions of the Status and Role of Xhosa and English. System 30, pp. 499-515.

BARnetT, C. (1999), Broadcasting the Rainbow Nation: Media, Democracy, and Nation-Building in South Africa. Antipode 31, pp. 274-303.

Barnett, C. (2000), Language Equity and the Politics of Representation in South African Media Reform. Social Identities 6, pp. 63-90.

Coetzee, S., T. Du Plessis \& J. Messerschmidt (2001), Language Policy in Schools: A Critical Reflection. Paper presented at the Values, Education and Democracy Conference. Kirstenbosch, 22-24 February. Available at $<$ http://education.pwv.gov.za/ Conferences/Values/Stef_Coetzee_etc.htm>, accessed April 2001.

Department of Education South Africa (DESA) (1994), South Africa's New Language Policy. Pretoria.

Department of Education South Africa (DESA) (1995), White Paper 1 on Education and Training. Pretoria: Government Gazette no. 16725.

Department of Education South Africa (DESA) (1997), Language in Education Policy. Pretoria: Government Gazette no. 18546. 
Department of Education South Africa (DESA) (1999a), Status Report for the Minister of Education. Pretoria.

Department of Education South Africa (DESA) (1999b), Call to Action! Mobilizing citizens to build a South African education and training system for the 21st century. Pretoria.

Department of Education South Africa (DESA) (2000a), Implementation Plan for Tirisano January 2000-December 2004. Pretoria.

Department of Education South Africa (DESA) (2000b), Corporate Plan January 2000-December 2004. Pretoria.

Department of Education South Africa (DESA) (2000c), Report of the Working Group on Values in Education. Pretoria. Available at <http://education. pwv.gov.za/Policies\% 20and\%20Reports / 2000 Reports/Values.htm>, accessed July 2000.

Department of Education South Africa (DESA) (2002), Values in Education Programme of Action. Pretoria. Available at <http://education.pwv.gov.za/DoE_ Sites/Values/VALUESIN.PDF>, accessed July 2003.

DERridA, J. (1998), Monolingualism of the Other; or, The Prosthesis of Origin. Stanford CA: Stanford University Press.

Desai, Z. (2001), Multilingualism in South Africa with Particular Reference to the Role of African Languages in Education. International Review of Education 47, pp. 323-339.

Desbiens, C. (2002), Speaking in Tongues, Making Geographies. Environment and Planning D: Society and Space 20, pp. 1-3.

Desforges, L. \& R. Jones (2001), Geographies of Languages/Languages of Geography. Social E Cultural Geography 2, pp. 261-264.

Fanon, F. (1963), The Wretched of the Earth. New York: Grove Press.

FAnon, F. (1986), Black Skin, White Masks. London: Pluto Press.

Garcia-Ramon, M.-D. (2003), Globalization and International Geography: the Questions of Languages and Scholarly Traditions. Progress in Human Geography 27, pp. 1-5.

Gerwel, G.J. (2002), Report on the Position of Afrikaans in the University System. Available at $<$ http://education.pwv.gov.za/DoE_Sites/Higher_ Education/Gerwel\%20Language\%20Policy.doc $>$, accessed June 2003.

Grey, J. (2001a), Difficult Moulds to Break. The Teacher, 5 June.

Grey, J. (2001b), Black Learners Claim Inequality Drove Them from School. The Teacher, 5 June.
Krog, A. (1999), Country of My Skull. London: Vintage.

Lubisi, D. (1997), Grade 1 Books Rejected for Poor Language. African Eye News Service, 27 November.

Lubisi, D. (1998a), Rebel Afrikaans School Finally Begins Registering English Pupils. African Eye News Service, 20 January.

Lubisi, D. (1998b), Demographic Shifts Force Afrikaans Schools to Begin Admitting English Pupils. African Eye News Service, 29 January.

Lubisi, D. (1998c), English Pupils Stay Away Despite Dual-Medium Victory. African Eye News Service, 5 March.

Mвекi, T. (1999), Address to the Afrikaanse Taal en Kultuurvereniging (ATKV), 27 August. Available at <http://www.anc.org.za/ancdocs/history/mbeki/ 1999/tm0827a.html>, accessed June 2003.

Nash, C. (2002), Cultural Geography: Postcolonial Cultural Geographies. Progress in Human Geography 26, pp. 219-230.

Ngũgĩ WA Thiong'o (1986), Decolonising the Mind: The Politics of Language in African Literature. London: James Currey.

PaAsi, A. (1999), The Changing Pedagogies of Space: Representation of the Other in Finnish School Geography Textbooks. In: A. BuTtimer, S.D. BRunN \& U. WARDEnga, eds., Text and Image: Social Construction of Regional Knowledges, pp. 226-237. Leipzig: Institut für Länderkunde.

Ploszajska, T. (1999), Geographical Education, Empire and Citizenship: Geography Teaching and Learning in English Schools, 1870-1944. RGS/IBG Historical Geography Research Series, No. 35.

Republic of South Africa (1996), Constitution of the Republic of South Africa. Pretoria. Available at <http://www.polity.org.za/html/govdocs/constitution/ saconst.html>, accessed June 2003.

Rangan, H. \& M. Gilmartin (2002), Gender, Traditional Authority, and the Politics of Rural Reform in South Africa. Development and Change 33, pp. 633-658.

Retamar, R.F. (1989), Caliban: Notes Toward a Discussion of Culture in Our America. In: R.F. Retamar, Caliban and Other Essays, pp. 3-45. Minneapolis: University of Minnesota Press.

Schnell, I. (1999), Narratives and Styles in the Regional Geography of Israel. In: A. Buttimer, S.D. Brunn \& U. WARDEnga, eds., Text and Image: Social Construction of Regional Knowledges, pp. 215225. Leipzig: Institut für Länderkunde.

Scotr, J. (1998), Seeing Like A State: How Certain Schemes to Improve the Human Condition Have 
Failed. New Haven \& London: Yale University Press.

Short, J.R., A. Boniche, Y. Kim \& P. Li Li (2001), Cultural Globalization, Global English and Geography Journals. Professional Geographer 53(1), pp. 1-11.

South African Institute of Race Relations
(1998), South Africa Survey 1997-1998. Braamfontein: SAIRR.

Willinsky, J. (1998), Learning to Divide the World: Education at Empire's End. Minneapolis \& London: University of Minnesota Press.

Woods, D. (1978), Biko. New York \& London: Paddington Press. 